\title{
DEPENDENCE OF THE PHOSPHATE SORPTION CAPACITY ON THE ALUMINIUM AND IRON IN FINNISH SOILS
}

\author{
Armi KaIla \\ University of Helsinki, Department of Agricultural Chemistry
}

Received October 1. 10. 1963

In order to avoid losses of phosphate by leaching, Liebig made his patent manure difficultly soluble. Soon it was found, however, that the factor which restricts the availability for plants of the applied phosphate fertilizers is not leaching, but a more or less intensive fixation of phosphorus by the soil constituents. The mechanism of this retention is not completely known, yet, but there is strong evidence that the most important role in acid soils is played by aluminium and iron compounds, and in alkaline and calcareous soils by calcium and aluminium (cf. 3). In order to test to what degree the capacity of our more or less acid soils to sorb phosphate may be explained on the basis of their content of aluminium and iron, the studies were carried out the main results of which are reported in the present paper.

The phosphate retention capacity of a soil is a vague quantity the level of which largely depends on the method used for its determination. In the present work the ability of a soil to sorb phosphate is estimated by the slightly modified method introduced by TERÄSvUORI (8). It is based on the Freundlich adsorption isotherm $\mathrm{y}=\mathrm{k} \times \mathrm{c}^{\frac{1}{n}}$ in which $\mathrm{y}=$ the amount of $\mathrm{P}$ sorbed by the soil, $\mathrm{c}=$ the final equilibrium concentration of the solution, and $\mathrm{k}$ and $\mathrm{n}$ are constants. According to TERÄSVUORI, the coefficient $k$ is closely related to the phosphate sorption capacity of a soil. Russell and PREscotT (7) in 1916 emphasized that $k$ wrepresents the tenacity with which the soil keeps its phosphate, or the reluctance with which the soil parts with its phosphate under the conditions of the experiment».

In a previous work (4), TERÄSVUORI's method was applied to the estimation of the sorption of phosphorus by virgin peat samples. It was found that in this material 76.5 per cent of the variation in the factor $k$ could be explained by the variation in the contents of aluminium and iron soluble in diluted hydrochloric acid. Aluminium appeared to play a more important role in the phosphorus sorption of these peat samples than did iron under the experimental conditions. 
In the present work, a number of samples of Finnish mineral soils is analyzed by TERÄSVUORI's procedure, and the relationship between the indicator of the phosphate sorption capacity, $k$, and some other soil properties is studied. Attention is paid to the following analytical data: the soil texture, the soil $\mathrm{pH}$, the contents of organic carbon, and aluminium and iron extracted by acid ammonium oxalate or by diluted hydrochloric acid.

\section{Material and methods}

The material consists of 213 samples of the plough layer of cultivated mineral soils from different parts of the country. In addition, 27 samples of cultivated humus soils, and 25 samples of virgin mineral soils were analyzed. 125 samples were collected from the deeper layers, from 20 to $60 \mathrm{~cm}$, from 55 places.

All the samples were air-dried and ground. They were divided, according to the results of mechanical analysis, into the following groups:

$\begin{array}{llc} & <0.002 \mathrm{~mm} & >0.02 \mathrm{~mm} \\ \text { sand and fine sand soils } \ldots \ldots & <30 \% & >50 \% \\ \text { loam and silt soils } \ldots \ldots \ldots & <30 \% & <50 \% \\ \text { clay soils } \ldots \ldots \ldots \ldots \ldots \ldots & >30 \% & \end{array}$

There are 109 samples of sand and fine sand soils, 103 samples of loam and silt soils, and 151 samples of clay soils. The humus soils represent soils between the proper peat soils and mineral soils, and they contain more than 8.5 per cent of organic carbon.

Soil $\mathrm{pH}$ was measured in a 1 to 2.5 suspension in $0.02 \mathrm{~N} \mathrm{CaCl}_{2}$ by the glass electrode. The content of organic carbon was determined by the WALKLEY method (9), using the iodometric titration.

Aluminium and iron were extracted by TАмм's acid ammonium oxalate solution and by $0.1 \mathrm{~N} \mathrm{HCl}$. The ratio of soil to solution was 1 to $20 \mathrm{in}$ both cases, and the period of extraction was two hours. Aluminium was determined by the Aluminon method and iron by the sulfosalicylic acid procedure after the organic matter in the oxalate extract was destructed by ignition.

In order to get the necessary values for $\mathrm{y}$ and $\mathrm{c}$ in the Freundlich equation $\mathrm{y}=\mathrm{k} \times \mathrm{c}^{\frac{1}{\mathrm{n}}}$ for the calculation of the coefficient $k$, the final equilibrium concentrations, $c_{1}$ and $c_{2}$, of phosphorus in the solution and the corresponding amounts of sorbed phosphorus, $\mathrm{y}_{1}$ and $\mathrm{y}_{2}$, were determined in the following way which to some extent differs from the original procedure used by TERÄsvUORI (8). Two $10 \mathrm{~g}$-samples of soil were weighed into $300 \mathrm{ml}$ Erlenmeyer flasks, and $100 \mathrm{ml}$ of $0.0005 \mathrm{M} \mathrm{KH}_{2} \mathrm{PO}_{4}$ solution was added to one of them, to the other one $100 \mathrm{ml}$ of $0.005 \mathrm{M} \mathrm{KH}_{2} \mathrm{PO}_{4}$ solution. The suspensions were heated, with occasional shaking, on a boiling water-bath for two hours on two successive days in order to reach, at least approximately, an equilibrium between the $\mathrm{P}$ in the solution and the $\mathrm{P}$ in the soil. The suspensions were filtrated through paper, and the $\mathrm{P}$ concentrations, 
Table 1. Soil samples, mean values and standard deviations for the groups

\begin{tabular}{|c|c|c|c|c|c|c|c|c|c|c|c|}
\hline \multirow[t]{2}{*}{ Soil group } & \multirow[t]{2}{*}{$\begin{array}{c}\text { Number } \\
\text { of } \\
\text { samples }\end{array}$} & \multicolumn{2}{|c|}{$\mathrm{pH}$} & \multicolumn{2}{|c|}{ Org. C \% } & \multicolumn{2}{|c|}{$\begin{array}{c}\mathrm{Al} \\
\text { extracted by } \\
\mathrm{mmol} / \mathrm{kg}\end{array}$} & \multicolumn{2}{|c|}{$\begin{array}{c}\mathrm{Fe} \\
\mathrm{NH}_{4} \text {-oxalate } \\
\mathrm{mmol} / \mathrm{kg}\end{array}$} & $\begin{array}{l}\mathrm{Al} \\
\text { extracted by } \\
\mathrm{mmol} / \mathrm{kg}\end{array}$ & $\begin{array}{c}\mathrm{Fe} \\
0.1 \mathrm{~N} \mathrm{HCl} \\
\mathrm{mmol} / \mathrm{kg}\end{array}$ \\
\hline & & mean & s & mean & s & mean & s & mean & s & mean & mean \\
\hline
\end{tabular}

Sand and fine sand soils

$\begin{array}{lllllllllllllll}\text { Topsoil, cultivated } & \ldots & 57 & 5.4 & 0.5 & 3.0 & 1.0 & 104 & 58 & 62 & 27 & 51 & 26 & 9 & 5\end{array}$

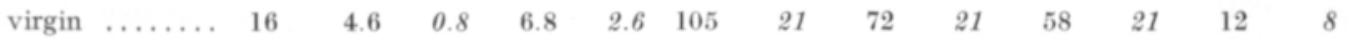

$\begin{array}{lllllllllllllll}\text { Subsoil, cultivated } & \ldots & 25 & 5.2 & 0.3 & 0.8 & 0.6 & 153 & 77 & 67 & 37 & 79 & 42 & 6 & 3\end{array}$

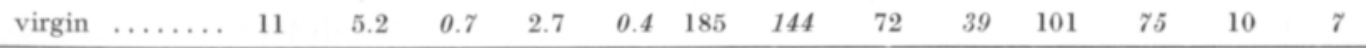

oam and silt soils

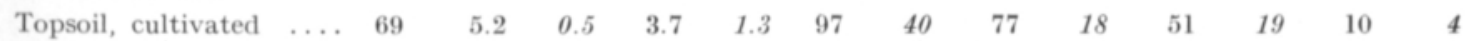

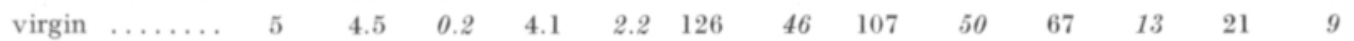

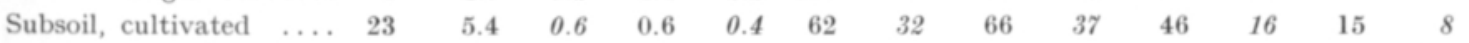

$\begin{array}{llllllllllllll}\text { virgin } \ldots \ldots & 6 & 5.8 & 0.9 & 0.5 & 0.4 & 80 & 83 & 64 & 49 & 53 & 24 & 15 & 4\end{array}$

lay soils

$\begin{array}{llllllllllllllll}\text { Topsoil, cultivated } & \ldots & 87 & 5.3 & 0.5 & 4.1 & 1.4 & 130 & 67 & 113 & 54 & 74 & 34 & 14 & 8\end{array}$

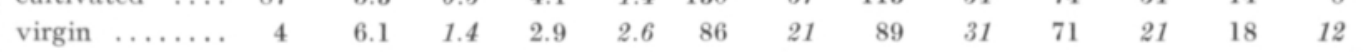

$\begin{array}{lllllllllllllll}\text { Subsoil, cultivated } & \ldots & 46 & 5.5 & 0.9 & 0.8 & 0.7 & 94 & 42 & 89 & 65 & 93 & 30 & 25 & 9\end{array}$

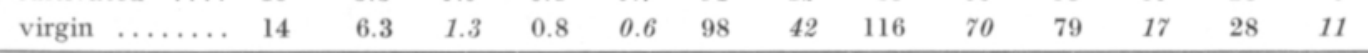

Humus soils

$\begin{array}{lllllllllllllll}\text { Topsoil, cultivated } & \ldots & 27 & 4.8 & 0.4 & 15.1 & 5.3 & 150 & 43 & 106 & 46 & 90 & 18 & 15 & 9\end{array}$

in $\mathrm{mg} / \mathrm{l}$, of the filtrates were taken for the values of $c_{1}$ and $c_{2}$, respectively. The corresponding $\mathrm{P}$ contents in the soil were calculated by adding to the amount of mexchangeable" $\mathrm{P}$ in the soil, $\mathrm{y}_{0}$, the amounts sorbed from the respective phosphate solutions. Thus $\mathrm{y}_{1}=\mathrm{y}_{0}+155-10 \mathrm{c}_{1}$, and $\mathrm{y}_{2}=\mathrm{y}_{0}+1550-10 \mathrm{c}_{2}$, both expressed as $\mathrm{P} \mathrm{mg} / \mathrm{kg}$ of soil. The amount of mexchangeablen $\mathrm{P}$ was determined by shaking a 4-g-sample of soil for 2 hours in the first day, and for 4 hours in the second day in $200 \mathrm{ml}$ of a solution $0.1 \mathrm{~N}$ with respect to both $\mathrm{KOH}$ and $\mathrm{K}_{2} \mathrm{CO}_{3}$. The suspension was let stand over night, and the dark organic matter was precipitated from an aliquote by sulfuric acid before the determination of $\mathrm{P}$. The coefficient $k$ was calculated according to the equation

$$
\log \mathrm{k}=\frac{\log \mathrm{y}_{1} \log \mathrm{c}_{2}-\log \mathrm{y}_{2} \log \mathrm{c}_{1}}{\log \mathrm{c}_{2}-\log \mathrm{c}_{1}}
$$

\section{Results}

In Table 1 the groups of the soil samples are characterized by the mean values of $\mathrm{pH}$, the contents of organic carbon, and aluminium and iron extracted by acid ammonium oxalate or by diluted hydrochloric acid. As a measure of variation, the standard deviation for each group is given. 
In comparing the different soil groups, attention must be paid to the fact that, particularly, the groups of virgin soils are very small. On the average, even the cultivated soils are distinctly acid, although the fairly high standard deviation of some of the groups indicates that variation in the $\mathrm{pH}$ values is large. The rather high average $\mathrm{pH}$ of the virgin subsoil samples of the clay soils is due to the large number of typical glacial clay soils in this group.

The organic carbon content of the cultivated surface soils tends to increase from sand to clay samples. A similar tendency may be found in the ammonium oxalate soluble iron. In the sand and fine sand soils, the content of iron appears to be far lower than the corresponding amount of aluminium extracted by ammonium oxalate; in the groups of the soils of a finer texture the difference is less marked or negligible. In all the soil groups the diluted mineral acid has extracted considerably higher amounts of aluminium than of iron.

Table 2. Indicator of the phosphate sorption capacity, $k$, in various kind of soils

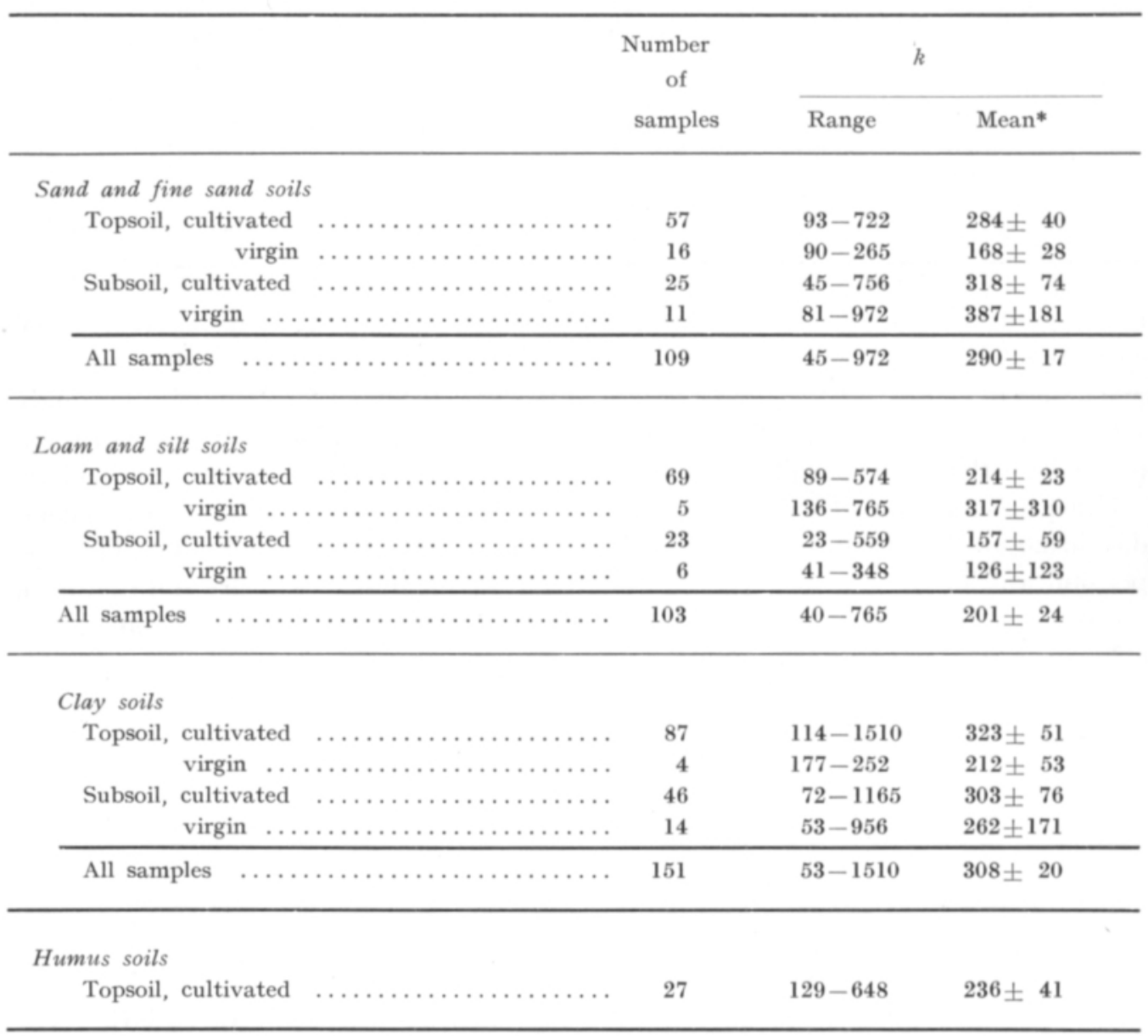

* Confidence limits of the means at the 95 per cent level 
According to the data in Table 2, the numerical value of $k$, or the indicator of the phosphate sorption capacity ranges in the present material from 40 to 1510 . The variation is large even within the same kind of soils. On the average, $k$ appears to be lower in the group of the loam and silt soils than in the samples of a finer or a coarser texture. Owing to the small number of samples from virgin soils, no conclusions may be drawn from the possible differences between the cultivated soils and the virgin soils in regard to this property. The topsoil samples of the sand and fine sand soils tend to have a somewhat lower $k$ than those of the subsoil, but the opposite may be true with the samples of loam and silt soils. The humus soils do not differ from the proper mineral soils.

It must be emphasized that $k$ does not correspond to the maximum sorption capacity, not even to the absolute amount of phosphorus sorbed by the soil sample under the conditions of the experiment. It is only supposed to be closely correlated with the more or less vague sorption capacity. The amounts of phosphorus retained from the $0.005 \mathrm{M} \mathrm{KH}_{2} \mathrm{PO}_{4}$-solution by the present samples ranged from no retention to a complete retention. When added to the amount of the original exchangeable phosphorus in the samples, the total amount of sorbed phosphorus ranged from 170 to $2000 \mathrm{mg} / \mathrm{kg}$ of soil.

The relation between $k$ and the soil $\mathrm{pH}$, the contents of carbon, aluminium and iron was first studied by calculating the total linear correlation coefficients

Table 3. Total linear correlation coefficients for the relation between $k$ and other variables

\begin{tabular}{|c|c|c|c|c|c|c|c|c|}
\hline \multirow[t]{2}{*}{ Soil group } & \multirow{2}{*}{$\begin{array}{c}\text { Number } \\
\text { of } \\
\text { samples }\end{array}$} & \multirow[b]{2}{*}{$\mathrm{pH}$} & \multirow[b]{2}{*}{ Org. C \% } & \multicolumn{3}{|c|}{ Acid oxalate soluble } & \multicolumn{2}{|c|}{$0.1 \mathrm{~N} \mathrm{HCl}$-soluble } \\
\hline & & & & $\mathrm{Al}$ & $\mathrm{Fe}$ & $\mathrm{Al}+\mathrm{Fe}$ & Al & $\mathrm{Fe}$ \\
\hline \multicolumn{9}{|l|}{ Sand and fine sand } \\
\hline Topsoil, cultivated & 57 & 0.15 & $0.31^{*}$ & $0.77 * * *$ & $0.53 * * *$ & $0.77 * * *$ & $0.77 * * *$ & $0.32 *$ \\
\hline Subsoil $\ldots \ldots \ldots$ & .. 36 & 0.14 & 0.20 & $0.86^{* * *}$ & $0.57 * * *$ & $0.84 * * *$ & $0.77^{* * *}$ & 0.10 \\
\hline All samples $\ldots \ldots$. & .. 109 & $0.22 *$ & -0.18 & $0.77 * * *$ & $0.59^{* * *}$ & $0.78^{* * *}$ & $0.62 * * *$ & $0.21 *$ \\
\hline \multicolumn{9}{|l|}{ Loam and silt } \\
\hline Topsoil, cultivated & $\begin{array}{ll}\ldots & 69\end{array}$ & $-0.28^{*}$ & $0.40^{* * *}$ & $0.65 * * *$ & $0.66^{* * *}$ & $0.68 * * *$ & $0.58 * * *$ & 0.04 \\
\hline Subsoil $\quad \ldots \ldots \ldots \ldots$ & . 29 & $-0.60 * * *$ & $0.38^{*}$ & $0.65 * * *$ & $0.69^{* * *}$ & $0.68 * * *$ & 0.19 & 0.21 \\
\hline All samples $\ldots \ldots$. & $\ldots 103$ & $-0.47^{* * *}$ & $0.37^{* * *}$ & $0.66^{* * *}$ & $0.73^{* * *}$ & $0.72^{* * *}$ & $0.44 * * *$ & $0.23^{*}$ \\
\hline \multicolumn{9}{|l|}{ Clay } \\
\hline Topsoil, cultivated & . 87 & $-0.41^{* * *}$ & $0.40^{* * *}$ & $0.88^{* * *}$ & $0.54^{* * *}$ & $0.87 * * *$ & $0.75^{* * *}$ & $0.29 * *$ \\
\hline Subsoil $\quad \ldots \ldots \ldots \ldots$ & . 60 & $-0.71^{* * *}$ & $0.76^{* * *}$ & $0.91 * * *$ & $0.87 * * *$ & $0.91 * * *$ & 0.06 & $0.65^{* * *}$ \\
\hline All samples $\ldots \ldots$. & $\ldots 151$ & $-0.55^{* * *}$ & $0.31^{* * *}$ & $0.84^{* * *}$ & $0.70^{* * *}$ & $0.87 * * *$ & $0.45^{* * *}$ & $0.35^{* * *}$ \\
\hline \multicolumn{9}{|l|}{ Humus } \\
\hline Topsoil, cultivated & .. 27 & -0.31 & 0.04 & $0.63^{* * *}$ & $0.68^{* * *}$ & $0.74^{* * *}$ & $0.43^{*}$ & $0.53^{*}$ \\
\hline All samples & .. 390 & $-0.32 * * *$ & 0.04 & $0.75^{* * *}$ & $0.65^{* * *}$ & $0.80^{* * *}$ & $0.51 * * *$ & $0.44^{* * *}$ \\
\hline
\end{tabular}

${ }^{*}$ Significant at the $5 \%$ level ${ }^{* *}$ Significant at the $1 \%$ level ***Significant at the $0.1 \%$ level 
between $k$ and the other variables. The results are recorded in Table 3 . In order to get larger populations, the subsoil samples from virgin and cultivated soils were pooled.

There is no correlation between the values of $k$ and $\mathrm{pH}$ in the sand and fine sand soils and in the humus soils. In all the other groups some negative correlation exists, but it is fairly high only in the subsoil samples of the clay soils.

The correlation between $k$ and the content of organic carbon is noteworthy only in the subsoil samples of the clay soils. Some relation may be found also in the other groups of the clay soils and in the loam and silt soils.

A positive correlation of quite an other order exists between $k$ and the content of ammonium oxalate soluble aluminium in all the groups. It is particularly close in the samples of the clay soils. The lowest correlation is found in the humus soils and in the loam and silt soils. In these groups the correlation coefficients between the values of $k$ and the ammonium oxalate soluble iron are equal to, or somewhat higher than the corresponding correlation coefficients for the relation between $k$ and the ammonium oxalate soluble aluminium. In the other groups the correlation of $k$ with iron appears to be markedly lower than its correlation with aluminium. The total content of the ammonium oxalate soluble sesquioxides was calculated and its correlation with $k$ was found to be equal to the correlation between $k$ and aluminium in the sand and fine sand soils and the clay soils, but equal to the correlation with iron in the groups of loam and silt soils. Only in the small group of the humus soils and for the whole material a somewhat higher total linear correlation coefficient could be found for the relation between $k$ and the sum of the sesquioxides than between $k$ and aluminium or iron, respectively.

The correlation between $k$ and aluminium in the hydrochloric acid extract is fairly close only in the plough layer of the sand and fine sand soils and the clay soils, as well as in the subsoils of the former group. There is no correlation between the values of $k$ and the hydrochloric soluble iron except in the subsoil samples of the clay soils.

Thus the total linear correlation coefficients indicate a fairly close connection between the indicator of the phosphate sorption capacity and the contents of ammonium oxalate soluble aluminium and iron. Some more information may be get by calculating the partial correlation coefficients between $k$ and the variables studied. In Table 4 are recorded the results obtained when the effect of one, two, or three of the other variables is eliminated from the correlation between $k$ and ammonium oxalate soluble aluminium, or iron, or $\mathrm{pH}$, or the content of organic carbon, respectively.

The correlation between $k$ and ammonium oxalate soluble aluminium is markedly lowered in the groups of loam and silt soils and humus soils when the effect of ammonium oxalate soluble iron is eliminated. In all the other groups the corresponding decrease is fairly low. The elimination of the effects of $\mathrm{pH}$ or the content of organic carbon does not significantly change the coefficients, except in the loam and silt soils.

In the sand and fine sand soils, the elimination of the effect of aluminium lowers the correlation between $k$ and iron to a considerable degree while its effect 
Table 4. Partial correlation coefficients between $k$ and $\mathrm{Al}$ and Fe soluble in acid ammonium oxalate, $\mathrm{pH}$ and the content of organic C

\begin{tabular}{|c|c|c|c|c|c|}
\hline \multirow[t]{2}{*}{ Soil groups } & \multirow{2}{*}{$\begin{array}{l}\text { Number } \\
\text { of } \\
\text { samples }\end{array}$} & & \multicolumn{3}{|c|}{ Correlation coefficients } \\
\hline & & $\mathbf{r}_{k} \mathrm{Al}$ & $\mathrm{r}_{k \mathrm{Al}, \mathrm{Fe}}$ & $\mathbf{r}_{k \mathrm{Al}, \mathrm{Fe} \mathrm{pH}}$ & $\mathbf{r}_{k \mathrm{Al}}, \mathrm{Fe} \mathrm{pH} \mathrm{C}$ \\
\hline Sand and fine sand $\ldots$. & 109 & $0.77 * * *$ & $0.64 * * *$ & $0.64^{* * *}$ & $0.63^{* * *}$ \\
\hline Loam and silt $\ldots \ldots \ldots$ & 103 & $0.66 * * *$ & $0.32 * *$ & $0.29 * *$ & $0.26^{*}$ \\
\hline Clay...$\ldots \ldots \ldots \ldots$ & 151 & $0.84^{* * *}$ & $0.75^{* * *}$ & $0.73^{* * *}$ & $0.78^{* * *}$ \\
\hline Humus $\quad \ldots \ldots \ldots \ldots \ldots$ & 27 & $0.63^{* * *}$ & 0.37 & 0.37 & - \\
\hline \multirow[t]{2}{*}{ All samples $\quad \ldots \ldots \ldots \ldots$} & 390 & $0.75^{* * *}$ & $0.63 * * *$ & $0.61 * * *$ & $0.63^{* * *}$ \\
\hline & & $\mathrm{r}_{k} \mathrm{Fe}$ & $\mathrm{r}_{k} \mathrm{Fe}, \mathrm{Al}$ & $\mathbf{r}_{k} \mathrm{Fe}, \mathrm{Al} \mathrm{pH}$ & $\mathbf{r}_{k} \mathrm{Fe}, \mathrm{Al} \mathrm{pH} \mathrm{C}$ \\
\hline Sand and fine sand $\ldots$. & 109 & $0.59^{* * *}$ & $0.26^{* *}$ & $0.28 * *$ & $0.30^{* *}$ \\
\hline Loam and silt $\ldots \ldots \ldots$ & 103 & $0.73^{* * *}$ & $0.54^{* * *}$ & $0.51 * * *$ & $0.51 * * *$ \\
\hline Clay $\ldots \ldots \ldots \ldots \ldots \ldots$ & 151 & $0.70^{* * *}$ & $0.51^{* * *}$ & $0.45^{* * *}$ & $0.46^{* * *}$ \\
\hline Humus $\quad \ldots \ldots \ldots \ldots \ldots$ & 27 & $0.68^{* * *}$ & $0.49^{*}$ & $0.49^{*}$ & - \\
\hline \multirow[t]{2}{*}{ All samples $\quad \ldots \ldots \ldots \ldots$} & 390 & $0.65^{* * *}$ & $0.43^{* * *}$ & $0.42 * * *$ & $0.48 * * *$ \\
\hline & & $\mathbf{r}_{k} \mathrm{pH}$ & $\mathbf{r}_{k} \mathrm{pH}, \mathrm{Al}$ & $\mathbf{r}_{k} \mathrm{pH}, \mathrm{Al} \mathrm{Fe}$ & $\mathbf{r}_{k} \mathrm{pH}, \mathrm{Al} \mathrm{Fe} \mathrm{C}$ \\
\hline Sand and fine sand $\ldots$. & 109 & $0.22^{*}$ & $0.28 * *$ & $0.30 * *$ & $0.27^{* *}$ \\
\hline Loam and silt $\ldots \ldots \ldots$ & 103 & $-0.47^{* * *}$ & $-0.30^{* *}$ & $-0.22^{*}$ & -0.19 \\
\hline Clay $\ldots \ldots \ldots \ldots \ldots \ldots$ & 151 & $-0.55^{* * *}$ & $-0.35^{* * *}$ & $-0.22 * *$ & $-0.26^{* *}$ \\
\hline Humus $\quad \ldots \ldots \ldots \ldots \ldots$ & 27 & -0.31 & -0.07 & 0.02 & - \\
\hline \multirow[t]{2}{*}{ All samples $\quad \ldots \ldots \ldots$} & 390 & $-0.32 * * *$ & $-0.18^{* *}$ & $-0.15^{* *}$ & -0.05 \\
\hline & & $\mathbf{r}_{k} \mathrm{C}$ & $\mathbf{r}_{k} \mathrm{C}, \mathrm{Al}$ & $\mathbf{r}_{k} \mathrm{C}, \mathrm{Al} \mathrm{Fe}$ & $\mathbf{r}_{k} \mathrm{C}, \mathrm{Al} \mathrm{Fe} \mathrm{pH}$ \\
\hline Sand and fine sand... & 109 & -0.18 & -0.14 & -0.19 & -0.15 \\
\hline Loam and silt $\ldots \ldots \ldots$ & 103 & $0.37^{* * *}$ & 0.05 & 0.16 & 0.12 \\
\hline Clay ................ & 151 & $0.31 * * *$ & $-0.33^{* * *}$ & $-0.38 * * *$ & $-0.40^{* * *}$ \\
\hline All samples $\ldots \ldots \ldots$. & 390 & 0.04 & $-0.27 * * *$ & $-0.36^{* * *}$ & $-0.42^{* * *}$ \\
\hline
\end{tabular}

*Significant at 5 per cent level ${ }^{* *}$ Significant at 1 per cent level ${ }^{* * *}$ Significant at 0.1 per cent level

is noteworthy but less marked in the other groups. Only in the clay soils the further elimination of the effect of $\mathrm{pH}$ decreases the correlation between $k$ and iron.

The fairly low negative correlation between $k$ and the $\mathrm{pH}$ values grows lower when the effect of the other variables is eliminated. The correlation between $k$ and the content of organic carbon reaches a statistically significant negative value when the effect of the other variables is eliminated in the clay soils and in the whole material.

Thus it seems that in the sand and fine sand soils and in the clay soils the closest correlation is found between $k$ and the content of ammonium oxalate soluble aluminium, while in the loam and silt soils $k$ is to a higher degree related to the content of ammonium oxalate soluble iron. The connection with $\mathrm{pH}$ is poor in all 
Table 5. Coefficients of determination, $\mathrm{r}^{2}$, and coefficients of multiple determination, $\mathrm{R}^{2}$

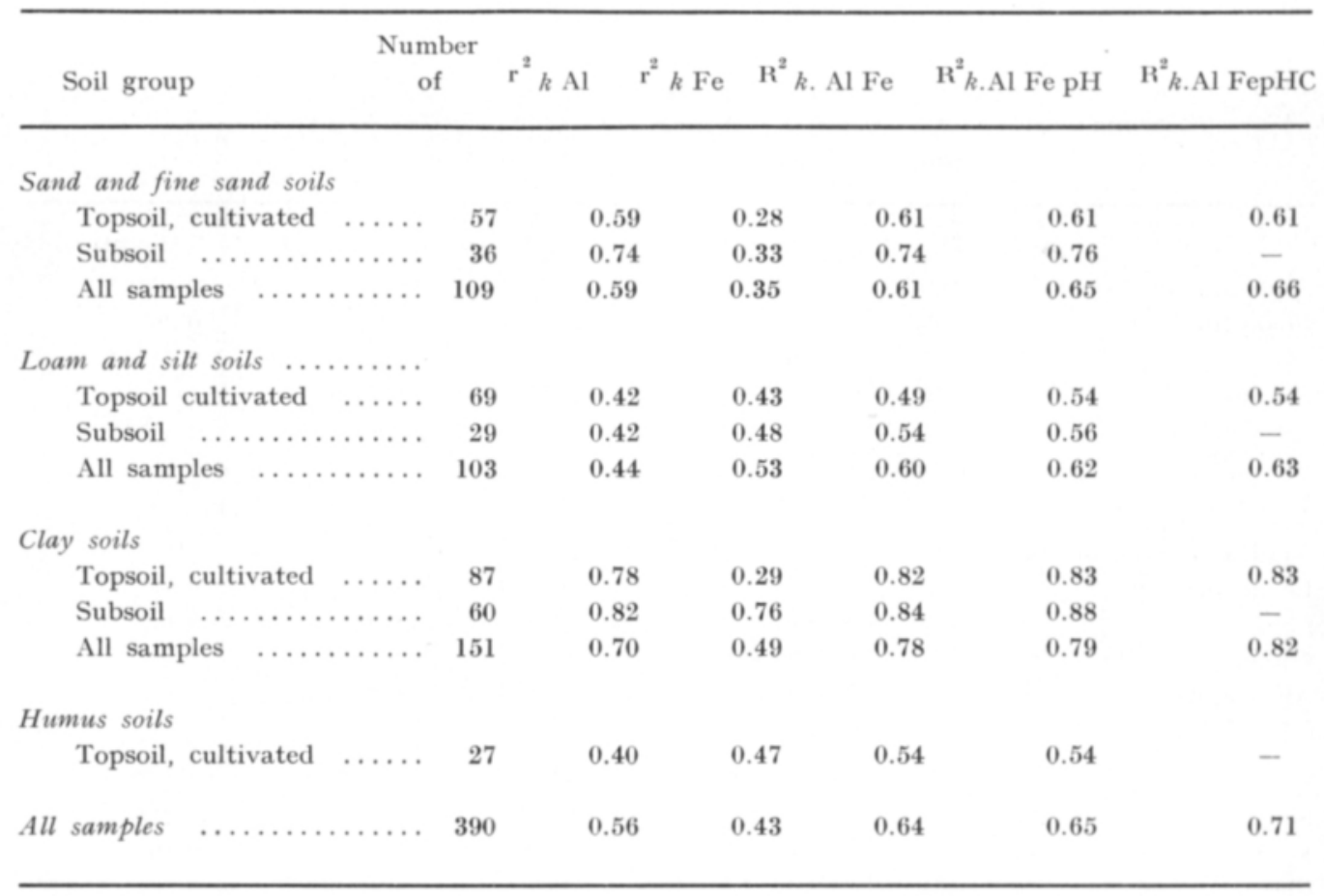

the groups, but apparently the content of organic carbon in the clay soils tends to be negatively correlated with $k$. This also holds true with all samples.

In order to measure the percentage to which the variation in $k$ may be explained by the variation in the other variables, the coefficients of determination, $r^{2}$, and the coefficients of multiple determination, $\mathrm{R}^{2}$, were calculated. The results are recorded in Table 5. It may be found that the variation in the content of ammonium oxalate soluble aluminium would explain only about 40 per cent of the variation in $k$ of the loam and silt soils and the humus soils, but from 70 to 82 per cent in the groups of the clay soils. The variation in the ammonium oxalate soluble iron may account for a very low part of the variation in $k$ of the sand and fine sand soils and the cultivated clay soils, while it in the loam and silt soils and in the humus soils tends to be more important than the aluminium content.

While the variation in the aluminium content explains 56 per cent, and the variation in the iron content 43 per cent of the variation of $k$ in all the samples, considering these two variables increases the variance in $k$ which may be explained to 64 per cent. Adding the content of iron does not increase the variance of $k$ which may be explained by the content of aluminium in the sand and fine sand soils and in the subsoil samples of clay soils. The increase is noteworthy in the loam and silt soils and in the humus soils. From 49 to 84 per cent of the variation in $k$ may be explained by the variation in the contents of aluminium and iron in the different soil groups. 
Adding $\mathrm{pH}$ brings up some further increase in the coefficients of multiple determination only in the groups of all the sand and fine sand samples, in the cultivated surface samples of loam and silt soils, and in the subsoil samples of the clay soils. Adding the content of organic carbon to the variables which are considered, increases the explainable variance in $k$ of all the clay soil samples and also of all the material to some degree, or to 82 and 71 per cent, respectively. In the clay soils, 81 per cent of the variance in $k$ may be explained by the variances in the content of aluminium, iron and organic carbon; the corresponding figure for all the samples is 69 per cent.

The relationships between $k\left(\mathrm{x}_{1}\right)$, the contents of ammonium oxalate soluble aluminium in mmols/ $\mathrm{kg}\left(\mathrm{x}_{2}\right)$, and iron in mmols $/ \mathrm{kg}\left(\mathrm{x}_{3}\right), \mathrm{pH}\left(\mathrm{x}_{4}\right)$ and the percentage of organic carbon $\left(\mathrm{x}_{5}\right)$ conform to the following regression equations:

In all the sand and fine and soils

$$
\mathrm{x}_{1}=1.48 \mathrm{x}_{2}+1.32 \mathrm{x}_{3}+68.4 \mathrm{x}_{4}-335.97
$$

The multiple correlation coefficient is $\mathrm{R}=0.804^{* * *}$, and the standard error of estimate $\mathrm{S}=109.5$.

In all the loam and silt soils

$$
\mathrm{x}_{1}=0.73 \mathrm{x}_{2}+2.19 \mathrm{x}_{3}-35.1 \mathrm{x}_{4}+155.67
$$

$\mathrm{R}=0.789^{* * *}$, and $\mathrm{S}=74.9$.

In all the clay soils

$$
\mathrm{x}_{1}=3.13 \mathrm{x}_{2}+1.37 \mathrm{x}_{3}-25.8 \mathrm{x}_{5}-126.19
$$

$\mathrm{R}=0.899^{* * *}$, and $\mathrm{S}=110.0$.

In all soils samples

$$
\mathrm{x}_{1}=1.91 \mathrm{x}_{2}+1.50 \mathrm{x}_{3}-11.0 \mathrm{x}_{5}-37.56
$$

$\mathrm{R}=0.829^{* * *}$ and $\mathrm{S}=108.1$.

The partial regression coefficients indicate that in the loam and silt soils iron is more important than aluminium in determining the retention of phosphate, while in all the other groups the phosphate retention capacity appears to depend more on aluminium than on iron content. The statistical studies show, however, that in addition to the contents of ammonium oxalate soluble aluminium and iron, also other factors must be considered. Obviously, the soil $\mathrm{pH}$ or the content of organic carbon do not play any particularly important role among these other factors. It may be mentioned that $k$ was not associated with the clay content of the samples to any marked degree.

\section{Discussion}

There appears to be some confusion in regard to the concept "phosphate sorption capacity". Often the amount of applied phosphate retained against certain extractant is taken to represent it, but attention had to be paid also to the initial amount of sorbed phosphate in the soil. Actually, rather few procedures have been proposed for the estimation of the phosphate sorption capacity of a soil. OLSEN and WATANABE (5) calculate the phosphorus adsorption maximum on the basis of the Lang- 
muir isotherm. Bass and Sieling (1) dissolve the problem by supposing that the amount of aluminium and iron extracted by citric acid is a measure of the relative phosphate-fixing capacity of an acid soil. In PIPER's (6) method for the determination of the anion-exchange capacity of the soil, the sample is saturated with phosphate and the amount of phosphate extracted by alkali from the treated sample is taken to represent the total exchange capacity. In the modification employed by Bass and Sieling (1), citric acid is substituted for sodium hydroxide as the extractant, and since the organic matter in the citric acid extract is oxidized before the determination of phosphorus, it is likely that in addition to inorganic phosphorus, also some organic phosphorus is included. This is not incorrect, since according to Williams (10) the organic phosphorus may satisfy about 10 per cent of the phosphate retention capacity.

In the procedure employed in the present work, no attention is paid to the organic phosphorus as a part of the initial soil phosphorus which satisfies the retention capacity. Allowance is made for sorbed inorganic phosphorus in the soil by taking into account the content of exchangeable or alkali-soluble phosphate in the original soil sample. On the other hand, it is a matter of opinion whether the latter will actually represent that part of the soil phosphorus which may be considered to be sorbed.

According to the general knowledge, the reaction of soluble phosphate with the soil constituents will largely depend on the $\mathrm{pH}$ at which it is taking place. PIPER (6) saturates the soil sample with phosphate at $\mathrm{pH}$ 4.0. In the present procedure the treatment occurs approximately at the soil $\mathrm{pH}$ : the $\mathrm{pH}$-values of the soil suspensions in the $\mathrm{KH}_{2} \mathrm{PO}_{4}$-solutions tend to be between the $\mathrm{pH}$-values measured for the soil in the water suspension and in the suspension in $0.02 \mathrm{~N} \mathrm{CaCl}_{2}$ in the ratio of 1 to 2.5. Thus the effect of the soil $\mathrm{pH}$ on the phosphate sorption capacity may be studied, at least to some extent, which would not be case if the treatment would be carried out at a constant and fairly low $\mathrm{pH}$, as it is done e.g. in the procedure by PIPER.

In the present material, the indicator of the phosphate sorption capacity, $k$, was not at all, or only slightly, correlated with the $\mathrm{pH}$ of the soil, except in the subsoil samples of loam and silt soil and clay soils where a linear negative relationship, though not any close one, was found. Quite of an other order were in most groups the total correlation coefficients between $k$ and the content of ammonium oxalate soluble aluminium. There exist however, marked differences in the different soil groups. In the clay soils, up to about 80 per cent of the variance in $k$ is associated with the content of ammonium oxalate soluble aluminium, while in the groups of loam and silt soils and in the humus soils this part is only about 40 per cent. In these two groups, the percentage to which the variance in $k$ is determined by ammonium oxalate soluble iron is somewhat higher than that determined by aluminium, but in the group of sand and fine sand soils the variation in the iron content explains only about one third of the variation in $k$. The contents of both aluminium and iron explain from 49 to 84 per cent of the variance in $k$, in the various groups of soil samples; for all the samples this part is only 64 per cent. If this is the case in general, the method of BASS and Sieling (1) for the determina- 
tion of the relative phosphate-fixing capacity on the basis of the content of aluminium and iron does not seem to be particularly reliable.

There may be several reasons for this result. First of all there is the coefficient $k$ itself. It is impossible to find out how closely it will be correlated with the unknown actual phosphate sorption capacity. It is only one of the conventional values supposed to give a relative measure for this quantity. Then it may be asked whether the acid ammonium oxalate solution will extract just that part of the sesquioxides which will be active in the sorption of phosphate, or at least closely correlated to this fraction. Yet, the association between $k$ and the amounts of aluminium, and particularly those of iron, soluble in $0.1 \mathrm{~N}$ hydrochloric acid was in the present material far less marked.

Some attention must also be paid to the possibility that the phosphate sorption capacity of a soil is a result of more than one mechanism of phosphate retention. It is quite likely, e.g. that the phosphate which is sorbed from the solution during the fairly short period of laboratory treatments is bound to the soil in a different and probably less intensive way than the native phosphate which has been exposed to several kind of reactions during the more or less long time of contact with the soil constituents. Actually, it has been found that soluble phosphate added to the soil is, at first, mainly fixed as aluminium bound phosphate, but in time it will gradually change to the less soluble iron bound phosphate (2).

When in addition to ammonium oxalate soluble aluminium and iron also $\mathrm{pH}$ and the carbon content are considered the part left to be explained in the variation of $k$ is in some soil groups slightly decreased. Thus, in the clay soils only from 12 to 18 per cent of the variation in $k$ is associated with the variation in some other factors. In the other groups, this part is far higher, in the loam and silt soils even up to 46 per cent.

Thus, further studies are necessary for finding out the factors on which the phosphate sorption capacity in different soils will depend. In this connection, the improvement of the methods will be of particular importance.

\section{$S u m m$ ary}

An attempt was made to study to what extent the capacity of the more or less acid soils in Finland to sorb phosphate may be explained on the basis of their content of aluminium and iron. The indicator of the phosphate sorption capacity was calculated on the basis of the Freundlich adsorption isotherm according to the procedure proposed by TERÄSvUORI (8). The material consisted of 390 samples from cultivated and virgin soils representing both topsoils and subsoils.

The indicator of the phosphate sorption capacity, the coefficient $k$, varied in the present material from 40 to 1510 . The mean values (with the confidence limits at the 95 per cent level) were for the 109 samples of sand and fine sand soils $290 \pm 17$, for the 103 samples of loam and silt soils $201 \pm 24$, for the 151 clay soils $308 \pm 20$, and for the 27 humus soils $236 \pm 41$.

The total linear correlation coefficients between $k$ and the soil $\mathrm{pH}$, and its 
contents of organic carbon or clay were low or negligible in most of the soil groups. The correlation of $k$ with the content of aluminium extracted by Tamm's acid ammonium oxalate was fairly close in the clay soils $\left(\mathrm{r}=0.84^{* * *}\right)$, lower in the sand and fine sand soils $\left(\mathrm{r}=0.77^{* * *}\right)$, and in the loam and silt soils, and in the humus soils it was rather poor $\left(\mathrm{r}=0.65^{* * *}\right.$ and $0.63^{* * *}$ resp.). The elimination of the effect of the ammonium oxalate soluble iron decreased the correlation in the two latter groups quite markedly (to $0.32^{* *}$ and 0.37 resp.), while the corresponding decrease in the coefficients for the former groups was less significant (to $0.64 * * *$ and $0.75^{* * *}$ resp.). The elimination of the effect of the ammonium oxalate soluble aluminium, on the other hand, decreased the correlation coefficients between $k$ and the ammonium oxalate soluble iron in the sand and fine sand soils from $0.59 * * *$ to $0.26^{* *}$, in the loam and silt soils from $0.73^{* * *}$ to $0.54 * * *$, in the clay soils from $0.70^{* * *}$ to $0.51^{* * *}$, and in the humus soils from $0.68^{* * * *}$ to $0.49^{*}$.

The part of variation in $k$ which could be explained on the basis of the variation in the contents of aluminium and iron was different in the different kind of soils. According to the coefficients of determination and the coefficients of multiple determination, the variance in the aluminium content determined 59 per cent of the variance in $k$ in the sand and fine sand soils and 70 per cent in the clay soils; considering also the content of iron increased this part to 61 per cent and 78 per cent, resp. In the loam and silt soils the variation in the iron content explained 53 per cent of the variation in $k$, in the humus soils this percentage was 47 . Considering both aluminium and iron, the proportion of the variance in $k$ which could be explained in these two groups was increased to 60 per cent and 54 per cent, resp.

Thus, in addition to the contents of ammonium oxalate soluble iron and aluminium, other factors must be found to explain the variation in the phosphate sorption capacity, particularly in other soil groups than in the clay soils. The soil $\mathrm{pH}$ and its content of organic carbon obviously play only a minor role among these ctors.

\section{REFERENCES}

(1) Bass, G. B. \& Sieling, D. H. 1950. Method for determining relative phosphate fixing capacity of acid soils. Soil. Sci. 69: $269-280$.

(2) Chang, S. C. \& ChU, W. K. 1961. The fate of soluble phosphate applied to soils. J. Soil Sci. 12: $286-293$.

(3) Hemwall, J. B. 1957. The fixation of phosphorus by soils. In Advances in Agronomy IX: 95112.

(4) KaIla, A. 1959. Retention of phosphate by peat samples. J. Sci. Agr. Soc. Finland 31: 215-225.

(5) Olsen, S. R. \& Watanabe, F. S. 1957. A method to determine a phosphorus adsorption maximum of soils as measured by the Langmuir isotherm. Soil Sci. Soc. Amer. Proc. 21: 144-149.

(6) Piper, C. S. 1944. Soil and plant analysis. New York, 368 p.

(7) Russell, E. J. \& Prescott, J. A. 1916. The reaction between dilute acids and the phosphorus compounds of the soil. J. Agric. Sci. 8: 65-110.

(8) TERÄSvuorI, A. 1954. Ưber die Anwendung saurer Extraktionslösungen zur Bestimmung des Phosphordüngerbedarfs des Bodens, nebst theoretischen Erörterungen über den Phosphorzustand des Bodens. Publ. Staatl. Landw. Versuchsw. Finland N:r 141. 
(9) WALKLEY, A. 1935. An examination of methods for determining organic carbon and nitrogen in soils. J. Agric. Sci. 25: 598-600.

(10) Williams, E. G. 1959. Influence of parent material and drainage conditions on soil phosphorus relationships. Agrochimica III: 279-309.

\title{
SELOSTUS:
}

\section{FOSFORIN PIDÄTYSKAPASITEETIN RIIPPUVUUS MAITTEMME ALUMINIUMIN JA RAUDAN PITOISUUDESTA}

\author{
Armi KaIla \\ Yliopiston maanviljelyskemian laitos, Helsinki
}

Käyttämällä Teräsvuoren menetelmän mukaisesti laskettua Freundlichin adsorptioyhtälön kerrointa $k$ osoittamaan maan suhteellista fosforinpidätyskykyä tutkittiin tämän suureen riippuvuutta maan liukenevan aluminiumin ja raudan pitoisuudesta 390 näytteen aineiston perusteella.

Tutkituissa hiekka- ja hietamaissa happamaan ammoniumoksalaattiin liukenevan aluminiummäärän vaihtelut selittivät $59 \% \quad k$ :n vaihtelusta ja savimaissa $70 \%$. Saman liuottimen uuttaman raudanpitoisuuden huomioon ottaminen lisäsi selitettävissä olevan osan $k: \mathrm{n}$ vaihtelusta edellisessä ryhmässä vain $61 \%: k s i$, jälkimmäisessä $78 \%$ :ksi. Hiue- ja hiesumaissa samoin kuin multamaissa $k$ nåytti riippuvan hiukan enemmän raudan kuin aluminiumin pitoisuudesta: rauta selitti $53 \%$ sen vaihtelusta edellisessä, $47 \%$ jälkimmäisessä tapauksessa ja aluminiumin huomioon ottaminen lisäsi selitettåvissä olevan osan $k: n$ vaihtelusta edellisessä tapauksessa $60 \%: \mathrm{ksi}$ ja jälkimmäisessä tapauksessa $54 \%$ :ksi.

Niiden tekijöiden joukossa, jotka maan aluminiumin ja raudan pitoisuuden ohella vaikuttavat sen fosforin pidätyskapasiteettiin, näytti maan reaktiolla ja orgaanisen hiilen pitoisuudella olevan verraten vähän merkitystä. 